\title{
O slovníkářství hravě a neotřele
}

Michaela Lišková - Martin Šemelík, eds.:

\section{Jak se píší slovníky aneb Lexikografie pro každého.}

Praha: Nakladatelství Lidové noviny, 2019, $261 \mathrm{~s}$.

ISBN 978-80-7244-718-9.

V minulém roce byla vydána popularizační kniha, která čtenářům předestírá zajímavosti z lexikografické teorie a praxe. Vzhledem k př́vlastku popularizační je kniha určena zejména laickým zájemcům o češtinu, pro které půjde zpravidla o první obeznámení se s tvorbou slovníků jako takovou.

V úvodní kapitole jsou vymezeny základní termíny (např. slovník, lexikografie), nastíněna je též základní typologie lexikonů nebo současné trendy ve slovníkářství, mj. spojené s tvorbou elektronických projektů a s tzv. občanskou vědou (spíše známou pod anglickými názvy citizen science nebo crowdsourcing). Posléze jsou popsány jednotlivé fáze vzniku slovníku, včetně řady úskalí, která čekají na každého lexikografa, jako je sběr materiálu, výběr slov do hesláře, slovníková makrostruktura (včetně dopodrobna popsaného problému hnízdování), forma slovníkového hesla, slovníková exemplifikace aj. Čtenář se tak zúčastní - slovy autorů - „castingu na slova do slovníku“, „ponoří se do heslové statě“, a dokonce se potká s „Davidy a Goliáši“, tj. s drobnými oblastními nářečními slovníky a s Př́ručním slovníkem jazyka českého coby dosud nejobjemnějším výkladovým slovníkem češtiny.

Autoři se ve výkladu opírají o základní literaturu z oboru, domácí i zahraniční, též o zkušenosti z tvorby dvou slovníkových děl, a to Akademického slovníku současné češtiny a Velkého německo-českého akademického slovníku. Autorský kolektiv je totiž tvořen z pracovníků Ústavu pro jazyk český AV ČR, v. v. i., a Ústavu germánských studií FF UK. Díky této zajímavé symbióze dvou pracovišt je umožněno nahlížet na probíraná témata z nových perspektiv, což je př́ínosné i pro tvůrce dalších slovníků (nářečních, propriálních, cizojazyčných, ...).

Kniha je určena široké veřejnosti, tomu je přizpůsoben její styl. Oproti klasickým odborným knihám, v nichž je zvykem suchopárný výklad s jednoznačnými formulacemi, se tu do popředí dostává vtip a nadsázka. V textu opakovaně vystupují třebas citoslovce, která bychom v odborných publikacích hledali marně, např. oops (s. 148), ufff (s. 153). Překvapí také zmínka o tom, že je na čase hnízdování „poslat do lexikografického důchodu“ (s. 65), označení předpon slovem chuděrky (s. 150) nebo přání, aby významy označené ve slovnících křížkem „odpočívaly v pokoji“ (s. 99). Pro některé texty je příznačná nejen jazyková expresivita, ale také dramatizace a snaha komunikovat se čtenářem. Ten je opakovaně oslovován, dokonce je vtažen do lexikografického procesu prostřednictvím úkolů, které mu autoři zadávají (s. 92 aj.).

Většina kapitol se nese v tomto hravém duchu, najdou se však i výjimky, které jsou spíše než pro laiky určeny odborníkům. K těmto patří např. část $O$ makrostruktuře a hnízdování..., která (až př́liš) detailně popisuje stav v dosavadních česko-německých slovnících, z nichž je bohatě citováno. Výklad je rozvláčný, nadto se duplikují informace, které čtenář jednak 
vyčte z výňatků ze zkoumaných slovníků, jednak ze samotného komentáře $k$ nim. Obdobně podrobné je Povídání o synonymech; zde je navíc název kapitoly zavádějící - namísto o synonymech pojednává především o moderních elektronických nástrojích pro lingvisty. Čtenáře z řad nelexikografů mohou tyto pasáže odradit; výhodou je však skutečnost, že kapitoly lze číst na přeskáčku, takže v př́padě potřeby si mohou čtenáři vybrat jinou kapitolu, která více vyhovuje jejich zájmům.

Kromě zmíněné nevyváženosti v kapitolách, která je však částečně pochopitelná vzhledem ke složení autorského kolektivu tvořeného 18 členy, lze vytknout jen drobnosti. Z nich výběrově zmíním třebas chybný výklad slova bažant, které $\mathrm{v}$ češtině funguje jednak jako pojmenování jistého druhu ptáka, jednak jako slangové označení vojína v prvním roce dř́vější povinné vojenské služby. $V$ knize se dočteme, že jde o dvě různá slova, tj. homonyma (bažant I ,druh ptáka', bažant II ,vojín'; s. 114-115). Jde přitom o př́pad polysémie, tzn. pod heslovým slovem bažant by měly být řešeny oba významy, nebot druhý je odvozen z prvního. Ve vojenském slangu přitom nejsou přenesené názvy živočichů ničím výjimečným, srov. další názvy pro nováčka jako drozd, havran, holub, muflon, myš, štěně aj. Jakožto homonyma jsou chápána též slova email jakožto pojmenování pro ,vrstvu sklovité hmoty na keramice aj. a email (sic!) pro ,zprávu posílanou elektronickou poštou' (s. 112-113). Avšak zde jde o zjevnou chybu; zatímco pravopis prvního slova je správný, tj. email (s výslovností [emaj]]), druhé slovo s významem ,elektronická zpráva se podle stávajících Pravidel českého pravopisu píše se spojovníkem, tj. e-mail (srov. též výslovnost odlišnou od prvního slova [ímejl]; možná je tu též dubleta mail). Tato skutečnost patrně není autorovi známa. V knize lze ostatně dohledat více míst, která by vyžadovala zásah korektora, výběrově např. „mezi předponou a první částí částí složeniny“ (s. 61), „až si budete chtít najít, z čeho se vyrábí váš oblíbený nápoj a nenapadne vás hledat gin pod džin“ (s. 71), „být se do prsou“ (s. 78), „o tyto barvy se podělily pouze dvě slova" (s. 103) aj.

V souhrnném pohledu jde však o maličkosti, na něž ovšem recenzentka, která si dobře nabrousila pero (čtenář tohoto textu promine aluzi na jednu obzvláště vtipnou kapitolu), musela upozornit. Předpokládám, že se kniha dočká kladného hodnocení jak u dalších jazykovědců, tak u běžných čtenářůu, kteří se zajímají o jazyky a rádi by nahlédli do „slovníkářské kuchyně“.

Autorům děkuji za nevšední vhled do jejich práce, řadu podnětů k zamyšlení a také za popularizaci lexikografie, potažmo jazykovědy.

Poděkování: Příspěvek vznikl na základě řešení projektu č. DG2OPo2OVVo29 Náreč̌ čěského jazyka interaktivně. Dokumentace a zpř̌stupnění mizejícího jazykového dèdictví jako nedílné součásti regionálních identit; poskytovatel podpory Ministerstvo kultury, Program NAKI II. 


\section{Marta Šimečková}

Czech Language Institute of the CAS, v. v. i.

\section{Veveří 97, 602 oo Brno}

Czech Republic

simeckova@ujc.cas.cz výjimky či omezení příslušných práv. 